\title{
Comparison of proximate compositions, antioxidant, and antiproliferative activities between blueberry and Sageretia thea (Osbeck) M.C.Johnst fruit produced in Jeju Island
}

\author{
Gyeong-A Ko ${ }^{1}$ So Yae $\mathrm{Koh}^{2} \cdot$ Ji-yeon $\mathrm{Ryu}^{3} \cdot$ Somi Kim Cho ${ }^{1,2,3,4}$ \\ 제주산 블루베리와 상동열매의 일반성분, 항산화 및 항증식 활성 비교
}

고경아 $^{1} \cdot$ 고소예 $^{2} \cdot$ 류지 연 ${ }^{3} \cdot$ 김소미 $1,2,3,4$

Received: 5 May 2017 / Accepted: 5 June 2017 / Published Online: 30 June 2017

(C) The Korean Society for Applied Biological Chemistry 2017

\begin{abstract}
This study was aimed to evaluate and compare the proximate composition, antioxidant and antiproliferative activities of Sageretia thea (Osbeck) M.C.Johnst (S. thea) fruit and blueberry. The calorific value, crude protein, crude fat, crude ash, and carbohydrate were higher in $S$. thea fruit than in blueberry. $S$. thea fruit and blueberry have different profile of free sugars, in which amounts of fructose, glucose, and maltose were much higher in $S$. thea fruit than in blueberry. The methanol extracts of $S$. thea fruit contain higher amounts of total polyphenol and anthocyanin compared to those of blueberry extracts. In additions, 2,2-diphenyl-1-picrylhydrazyl (DPPH), alkyl, and 2,2'-azinobis(3-ethylbenzothiazoline-6-sulphonic acid) (ABTS) radical scavenging activities are greater in $S$. thea fruit extracts. Ethyl
\end{abstract}

Somi Kim Cho $(\bowtie)$

E-mail: phd.kim.somi@gmail.com; somikim@jejunu.ac.kr

${ }^{1}$ Faculty of Biotechnology, College of Applied Life Sciences, SARI, Jeju National University, Jeju 63243, Republic of Korea

${ }^{2}$ Faculty of Advanced Convergence Technology and Science, Jeju National University, Jeju 63243, Republic of Korea

${ }^{3}$ School of Biomaterials Sciences and Technology, College of Applied Life Sciences, SARI, Jeju National University, Jeju 63243, Republic of Korea

${ }^{4}$ Subtropical Tropical Organism Gene Bank, Jeju National University, Jeju 63243, Republic of Korea

This is an Open Access article distributed under the terms of the Creative Commons Attribution Non-Commercial License (http://creativecommons. org/licenses/by-nc/3.0/) which permits unrestricted non-commercial use, distribution, and reproduction in any medium, provided the original work is properly cited. acetate fractions and $n$-butanol fractions of $S$. thea fruit and blueberry show the most potent scavenging activity in DPPH-, alkyl-, and ABTS-radical scavenging assay. The ethyl acetate fractions of $S$. thea fruit and blueberry are the richest fraction in polyphenol contents while the $n$-butanol fractions of those are the highest fraction in anthocyanin contents. Furthermore, both $S$. thea fruit and blueberry extracts protect human dermal fibroblast cells against a $\mathrm{H}_{2} \mathrm{O}_{2}$-induced oxidative stress. The antiproliferative activities of $n$-hexane and chloroform fraction from $S$. thea fruit and blueberry were observed in AGS human gastric cancer and MDA-MB-231 human breast cancer cells. Therefore, our results suggest for the first time that the antioxidant and antiproliferative activities of $S$. thea fruit is comparable to that of blueberry and the nutritional value of the former is even superior to that of the latter.

Keywords Antioxidant $\cdot$ Antiproliferative $\cdot$ Blueberry $\cdot$ Proximate compositions · Sageretia thea (Osbeck) M.C.Johnst

\section{서 론}

최근 들어 경제발전과 생활수준의 향상에 따라 건강한 삶을 지 향하는 식 문화가 확대되고 있다. 식품 소재들에 의한 질병예 방, 건강증진 효능 및 노화방지에 대한 효능이 밝혀지면서, 생 명현상유지뿐만 아니라 생리활성 측면에서 식품에 대한 관심이 증대되고 있다(Cho 등, 2010; Chung 2015).

베리류는 작은 열매가 모여 하나의 과실 형태를 유지하는 장 과류를 총칭하는 것으로, 기능성 식품에 대한 관심이 높아짐에 
따라 베리류의 섭취가 증가하고 있다(An 등, 2015). 특히, 블루 베리, 딸기, 라즈베리, 아로니아, 오디 등과 같은 베리류는 플라 보노이드계 색소인 anthocyanin이 다른 과일에 비해 풍부하고, phenolic acid 및 tannin과 같은 페놀화합물이 함유되어 있어 항 산화, 항암, 항염증, 심혈관계 질환 예방 등에 효과가 있다고 알 려져 있다(Seeram 2008; Lee 등, 2015). 대표적인 베리류 중 하나인 블루베리는 진달래과(Ericaceae) 산앵두나무속(Vaccinium) 에 속하는 식물로 주로 북아메리카 지역에 분포하고 있다. 블 루베리의 효능으로는 항산화(Sellappan 등, 2002), 항암(Seeram 등, 2006), 항당뇨(Martineau 등, 2006), 항치매(Papandreou 등, 2009) 등이 보고 된 바 있다.

상동나무(Sageretia thea (Osbeck) M.C.Johnst.)는 갈매나무과 (Rhamnaceae) 상동나무속(Sageretia)에 속하는 반상록성 활엽관 목으로, 지리적으로 아시아와 북아메리카에 분포하며 우리나라 에서는 제주도와 남해안 지역에 분포한다(Chung 등, 2004). 잎 은 가을철에 황색으로 변하고 일부는 월동하며, 꽃은 10-11월에 핀다. 열매는 다음해 4-5월에 흑자색으로 성숙하며, 블루베리와 색상이 매우 비슷하고 크기는 블루베리보다 두 배 정도 작은 편이다(Kim 등, 2011). 상동나무는 예로부터 우리나라와 중국에 서 감기, 발열, 간염, 피부병 치료 등에 사용되었다(Chung 등, 2009; Song 등, 2014). 상동나무는 주로 잎의 생리활성에 대해 연구가 되어 있으며, 활성산소 소거 및 $\mathrm{LDL}$ 산화억제와 같은 항산화 활성(Chung 등, 2009) 과 HIV-1 protease 억제 활성 (Park 등, 2002) 이 보고되었다. 또한, 상동나무 잎 추출물로부 터 분리된 myricitrin, 7-O-methylmyricitrin kaempferol, 3-O- $\alpha$ L-rhamnopyranoside, 7-O-methylquercetin 3-O- $\alpha$-L-rhamnopyranoside, 7-O-methylmearnsitrin 성분이 항산화 활성에 기인하는 것으로 보고되었다(Chung 등, 2004).

상동열매는 예로부터 식용으로 이용되어 왔으나, 아직까지 상 동열매의 영양학적 가치와 생리활성에 대한 인식이 부족하여 수 요 및 활용도가 낮은 편에 속한다. 따라서 본 연구에서는 제주 지역에서 생산된 상동열매와 블루베리의 일반성분, 항산화 및 항증식 활성을 비교 분석함으로써 상동열매의 산업적 활용을 위 한 기초자료를 제공하고자 한다.

\section{재료 및 방법}

\section{실험재료 및 시약}

Folin-Ciocalteu phenol reagent, sodium carbonate anhydrous, rutin, gallic acid, 2,2-azinobis(3-ethylbensothiazoline-6-sulfonic acid) diammonium salt (ABTS), potassium persulphate, 2,2diphenyl-1-picrylhydrazyl (DPPH), 2,2'-azobis(2-methylpropionamid) dihydrochloride (AAPH), $\alpha$-(4-pyridyl-1-oxide)-N-tert-butylnitrone (4-POBN), catechin, $\alpha$-tocopherol, cyanidin-3-rutinoside은 Sigma Aldrich Co. (St. Louis, MO, USA)로부터 구입하여 사용하였다. Dimethylsulfoxide (DMSO), 3-(4,5-dimethylthiazol-2-yl)-2,5diphenyltetrazolium bromide (MTT)는 Amresco Inc. (Solon, $\mathrm{OH}$, USA)에서 구입하였으며, F-12K, Dulbecco's modified Eagle's medium (DMEM), trypsin/EDTA, fetal bovine serum, 100× penicillin/streptomycin solution는 Invitrogen Inc. (Carlsbad, $\mathrm{CA}, \mathrm{USA}$ )에서 구입하였다.

\section{추출물 및 분획물의 조제}

본 실험에 사용된 상동열매(Sageretia thea (Osbeck) M.C.Johnst.) 는 2014년 5월 제주 서광 농가에서 재배한 것을 구입하였으며, 상동열매의 대조표본(Huikim8460)은 목포대학교 한약자원학과 김휘 교수에 의해 확인되었다. 블루베리(Vaccinium ashei)는 레 빗아이종으로 2014년 8월 제주 조천 농가에서 재배한 것을 구 매하였으며, 대조 표본(No. 2013/015)은 제주대학교 아열대·열 대생물유전자은행센터 문정용 박사에 의해 확인되었다. 상동열 매와 블루베리는 $-70{ }^{\circ} \mathrm{C}$ 에서 냉동 보관 하면서 추출시료로 사 용하였다. 총 폴리페놀 함량, 총 안토시아닌 함량 및 항산화 활 성 실험을 위한 추출물의 조제는 믹서기를 이용해 마쇄한 생 시료 $150 \mathrm{~g}$ 에 $80 \%$ 메탄올 $3 \mathrm{~L}$ 을 가하여 15 분 동안 sonication 을 3회 반복하여 추출한 뒤 whatman No. 2 여과지를 이용하 여 여과하였다. 각 추출물은 rotary vacuum evaporator를 이용 하여 $30{ }^{\circ} \mathrm{C}$ 에서 감압농축한 후, 냉동건조기(PVTFD10R, Ilsin, Korea)로 동결 건조하여 분말 상태로 만들어 메탄올 추출물을 얻었다. 건조된 메탄올 추출 시료 $7 \mathrm{~g}$ 에 증류수 $1 \mathrm{~L}$ 를 넣어 녹 인 후, 극성의 정도에 따라 헥산, 클로로포름, 에틸아세테이트, 부탄올 및 물 $1 \mathrm{~L}$ 를 이용하여 순차적으로 용매 분획하고 여과 하였다. 각각의 분획물들을 rotary vacuum evaporator로 농축한 후, 냉동건조기로 동결 건조하여 분말상태로 만들어 $-20{ }^{\circ} \mathrm{C}$ 에서 보관하면서 각 실험에 사용하였다.

\section{일반성분 분석}

일반성분은 $\mathrm{AOAC}$ 의 표준분석법(Horwitz 등, 1970) 및 식품공 전(Food and Association 2005) 에 준하여 측정하였다. 수분, 조단백질, 조지방 및 조회분은 각각 $105^{\circ} \mathrm{C}$ 상압건조법, $\mathrm{Kjeldahl}$ 법, 에테르 추출법 및 건식회화법으로 분석하였다. 탄수화물은 $100 \%$ 에서 수분, 조단백질, 조지방 및 조회분 함량을 제외한 값 으로 나타내었다. 유리당은 시료 $1-2 \mathrm{~g}$ 에 $50 \% \mathrm{CAN} 50 \mathrm{~mL}$ 을 가하여 10 분간 초음파 추출을 3 회 반복하였다. 추출한 시료액 은 Sep-Pak C18 cartridges (Waters, Milford, MA, USA)를 통과시킨 후, $0.45 \mu \mathrm{M}$ membrane filter (Woongki science co. Ltd., Seoul, Korea)로 여과하여 High performance liquid chromatography (HPLC, Water 2695)로 분석하였다. 유리당 분 석 column은 Prevail Carbohydrate $\mathrm{ES}(4.6 \times 250 \mathrm{~mm}, 5 \mu \mathrm{m}$, Grace, Columbia, MD, USA)을 사용하였고 이동상으로는 증류 수와 acetonitrile를 3:7로 혼합하여 사용하였으며 유속은 분당 $0.8 \mathrm{~mL}$ 였고, 검출기로는 Evaporative light scattering detector를 사용하였다. 함량은 농도별로 제조한 표준물질(Sigma Aldrich Co.)을 통해 HPLC로 분석하여 표준 검량선으로부터 유리당 함 량을 계산하였다.

\section{총 폴리페놀 함량}

총 폴리페놀 함량은 Cheung 등(2003)의 방법을 일부 수정하여 분석하였다. $125 \mu \mathrm{L}$ 의 시료에 $\mathrm{DW} 1,375 \mu \mathrm{L}$ 와 $2 \mathrm{~N}$ FolinCiocalteu's 시약 $0.5 \mathrm{~mL}$ 을 넣고 3 분 후, $10 \%$ sodium carbonate anhydrous $1 \mathrm{~mL}$ 을 가한 다음 암소에서 30 분 동안 반응시킨 후 분광광도계(Sunrise, Tecan, Salzburg, Austria)를 사용하여 700 $\mathrm{nm}$ 에서 흡광도를 측정하였다. 함량은 표준물질로 gallic acid를 이용하여 표준 검량선으로부터 시료의 총 폴리페놀 함량을 계 산하였으며 gallic acid equivalents (mg GAE/g)로 나타내었다. 


\section{총 안토시아닌 함량}

총 안토시아닌 함량은 $\mathrm{pH}$ differential method를 변형하여 측정 하였다. $190 \mu \mathrm{L}$ 의 $\mathrm{pH} 1.0$ buffer $(0.2 \mathrm{M} \mathrm{KCl}+0.2 \mathrm{M} \mathrm{HCl})$ 와 $\mathrm{pH} 4.5$ buffer $(0.2 \mathrm{M}$ potassium phosphate $+0.1 \mathrm{M}$ critic acid $)$ 를 각각 $10 \mu \mathrm{L}$ 의 시료와 혼합한 후 15 분간 정치한 후 분광광 도계(Sunrise, Tecan)를 사용하여 $520 \mathrm{~nm}$ 와 $700 \mathrm{~nm}$ 에서 흡광도 를 측정하였다. 함량은 cyanidin-3-rutinoside를 표준물질로 사용 하였으며, $\left(\mathrm{A}_{\lambda 520}-\mathrm{A}_{\lambda 700}\right) \mathrm{pH} 1.0-\left(\mathrm{A}_{\lambda 520}-\mathrm{A}_{\lambda 700}\right) \mathrm{pH} 4.5$ 값에 대하 여 표준 검량선을 작성하였고 시료의 총 안토시아닌 함량을 cyanidin-3-rutinoside equivalents $(\mathrm{mg} \mathrm{CE} / \mathrm{g}$ )로 나타내었다.

\section{$\mathrm{ABTS}$ 라디칼 소거 활성 측정}

$\mathrm{ABTS}$ 라디칼 소거 활성은 $\mathrm{Re}$ 등(1999)의 방법을 수정하여 측 정하였다. $\mathrm{ABTS}$ 용액은 $7 \mathrm{mM}$ ABTS과 $2.45 \mathrm{mM}$ potassium persulphate를 혼합해 하루 동안 암소에 보관하여 $\mathrm{ABTS}$ 라디칼 을 형성시켰으며, 분광광도계(UV1800 spectrophotometer, Shimadzu, Kyoto, Japan)를 사용하여 $734 \mathrm{~nm}$ 에서 흡광도 값이 $0.700 \pm 0.005$ 에 도달하도록 $\mathrm{DW}$ 로 희석하였다. 희석된 용액 900 $\mu \mathrm{L}$ 에 시료 $100 \mu \mathrm{L}$ 를 혼합하여 실온에서 2 분간 반응 시킨 후, $734 \mathrm{~nm}$ 에서 흡광도를 측정하였다. 양성대조군으로 $\alpha$-tocopherol 을 사용하였다.

\section{Electron spin resonance (ESR)을 이용한 DPPH 라디칼 소거 활성 측정}

각 시료에 의한 $\mathrm{DPPH}$ 라디칼에 대한 환원력을 이용하여 $\mathrm{DPPH}$ 라디칼 소거 활성을 측정하였다(Nanjo 등, 1996). $30 \mu \mathrm{L}$ 의 $60 \mu \mathrm{M} \mathrm{DPPH}$ 와 농도별로 준비한 시료를 혼합한 다음 10 초 간 강하게 교반하여 2 분동안 실온에서 반응시킨 후, capillary tube로 옮겨 JES-FA200 ESR spectrometer (JEOL, Tokyo, Japan)에서 측정하였다. 측정조건은 magnetic field $336.000 \mathrm{mT}$, power $5 \mathrm{~mW}$, sweep time 30초, sweep width $10 \mathrm{mT}$, frequency $9.43 \mathrm{GHz}$, modulation width $0.8 \mathrm{mT}$, amplitude 500 , time constant 0.03 초 였다. 양성대조군으로 catechin을 사용하였다.

\section{ESR을 이용한 Alkyl 라디칼 소거 활성 측정.}

Alkyl 라디칼 소거 활성은 Hiramoto 등(1993)의 방법에 따라 $\mathrm{ESR}$ 을 이용하여 측정하였다. Distilled water, $40 \mathrm{mM} \mathrm{AAPH}$, $40 \mathrm{mM}$ 4-POBN과 시료를 $20 \mu \mathrm{L}$ 씩 차례로 첨가하여 $37^{\circ} \mathrm{C}$ 항 온수조에서 30 분간 반응시킨 후, capillary tube로 옮겨 $\mathrm{ESR}$ spectrometer (JES-FA200, JEOL)에서 측정하였다. 측정조건은 magnetic field $336.000 \mathrm{mT}$, power $7 \mathrm{~mW}$, sweep time 30 초, sweep width $10 \mathrm{mT}$, frequency $9.43 \mathrm{GHz}$, modulation width $0.2 \mathrm{mT}$, amplitude 500, time constant 0.03 초 였다. 양성대조군 으로 catechin을 사용하였다.

\section{Gas chromatography-Mass spectrometer (GC-MS) 분석}

기체크로마토그래피 분석은 Shimadzu GC-MS (QP-2010, Shimadzu Co.)을 사용하여 수행하였으며, GC column은 Rtx-5MS (30 m length, $0.25 \mu \mathrm{m}$ diameter, $0.25 \mu \mathrm{m}$ thickness)를 사용하 였다. $\mathrm{GC}-\mathrm{MS}$ 의 분석조건은 오븐 온도는 $100^{\circ} \mathrm{C}$ 에서 1 분간 유 지하고 분당 $10^{\circ} \mathrm{C}$ 씩 승온하여 $140{ }^{\circ} \mathrm{C}$ 에서 3 분간 유지하였고, 다시 분당 $4{ }^{\circ} \mathrm{C}$ 씩 승온하여 $320^{\circ} \mathrm{C}$ 에서 10 분간 유지하며 분석
하였다. 운반 가스는 헬륨을 사용하여 total flow를 $1 \mathrm{~mL} / \mathrm{min}$ 으 로 분석을 진행하였고, 시료 주입 온도는 $250{ }^{\circ} \mathrm{C}$, transfer 온도 는 $280{ }^{\circ} \mathrm{C}$ 로 설정하였으며, SCAN mode로 $45-800 \mathrm{~m} / \mathrm{z}$ 범위에 서 분석하였다. 검출된 피크의 화합물 동정은 Willey 9 library database를 이용하여 library와 유사도가 $80 \%$ 이상인 화합물만 동정하였으며, 동정 된 화합물의 성분조성비는 피크의 intensity 를 기준으로 전체 피크에서 각 피크가 차지하는 비율을 기반으 로 산출하였다.

\section{세포주 및 배양}

실험에 사용된 인체 위암 세포주 AGS (human gastric adenocarcinoma) 와 인체 유방암 세포주 MDA-MB-231 (human breast adenocarcinoma) 은 한국세포주은행에서 분양 받았으며, 인간 유래의 정상 피부 세포인 human dermal fibroblast 세포는 제주대학교 의학전문대 학원 조문제 교수로부터 분양 받아 사용하였다. AGS 세포는 F$12 \mathrm{~K}, \mathrm{MDA}-\mathrm{MB}-231$ 과 fibroblast 세포는 DMEM에 $10 \%$ fetal bovine serum, 100 units $/ \mathrm{mL}$ penicillin, $100 \mu \mathrm{g} / \mathrm{mL}$ streptomycin 를 첨가하여 $37^{\circ} \mathrm{C}, 5 \% \mathrm{CO}_{2}$ incubator에서 배양하였다.

\section{산화적 스트레스로부터의 세포 보호 활성 측정}

$\mathrm{H}_{2} \mathrm{O}_{2}$ 에 의한 산화적 스트레스로부터의 세포 보호 활성은 MTT assay 방법을 이용하여 측정하였다(Carmichael 등, 1987). 세포 를 $4 \times 10^{3}$ cells/well의 농도로 96-well plate에 분주하고 16 시간 동안 배양하여 세포를 완전히 부착시킨 후, 시료와 $\mathrm{H}_{2} \mathrm{O}_{2}$ 를 4시 간 동안 동시 처리하였다. 배지를 제거한 다음 MTT 용액(5 $\mathrm{mg} / \mathrm{mL}$ )을 첨가하여 4시간 동안 배양한 후, 생성된 formazan crystal을 DMSO로 용해해 분광광도계(Sunrise, Tecan)를 이용하 여 $570 \mathrm{~nm}$ 에서 흡광도를 측정하였다.

\section{암세포 중식 억제 활성 측정}

암세포주(AGS, MDA-MB-231)에 대한 상동열매와 블루베리 메 탄올 추출물과 용매 분획물의 증식 억제 활성은 MTT assay 방 법을 이용하여 측정하였다. 각 세포를 $3 \times 10^{3}$ cells/well의 농도 로 96-well plate에 분주하고 16시간 동안 배양하여 세포를 완 전히 부착시킨 후, 시료를 48시간 처리하였다. 배지를 제거한 다음 MTT 용액 $(5 \mathrm{mg} / \mathrm{mL})$ 을 첨가하여 4시간 동안 배양한 후, 생성된 formazan crystal을 DMSO로 용해해 분광광도계 (Sunrise, Tecan)를 이용하여 $570 \mathrm{~nm}$ 에서 흡광도를 측정하였다.

\section{통계처리}

모든 실험은 3 회 반복으로 시행하였으며, 평균치와 표준편차로 나타내었다. 유의성 검증은 SPSS (SPSS Inc., Chicago, IL, USA)를 이용하여 t-test와 ANOVA one way를 시행하였다. 모 든 통계적인 유의성은 $p<0.05$ 수준에서 실시하였다.

\section{결과 및 고찰}

\section{일반성분 및 유리당 함량}

상동열매와 블루베리의 일반성분을 비교 분석한 결과, Table 1 에 나타낸 바와 같이 상동열매의 수분 함량은 $80.13 \pm 2.08 \%$, 블 루베리의 수분 함량은 $88.17 \pm 1.46 \%$ 로 측정되었다. 조단백질은 
Table 1 Proximate composition of $S$. thea and $V$. ashei fruit

\begin{tabular}{lcc}
\hline & S. thea & V. ashei \\
\hline Moisture (\%) & $80.13 \pm 2.08^{* 1)}$ & $88.17 \pm 1.46^{2}$ \\
Crude protein (\%) & $2.03 \pm 0.51$ & $1.07 \pm 0.12$ \\
Crude fat (\%) & $0.10 \pm 0.00$ & $0.10 \pm 0.00$ \\
Crude ash (\%) & $0.50 \pm 0.10^{*}$ & $0.20 \pm 0.00$ \\
Carbohydrate (\%) & $17.30 \pm 1.74^{*}$ & $10.57 \pm 1.21$ \\
Calories (kcal/ 100g) & $77.93 \pm 8.03^{*}$ & $46.97 \pm 5.68$ \\
\hline
\end{tabular}

${ }^{1)}$ Means indicated significant difference in comparing with $S$. thea

versus $V$. ashei at * $p<0.05$

${ }^{2)}$ Values are mean $\pm \mathrm{SD}(\mathrm{n}=3)$

상동열매가 $2.03 \pm 0.51 \%$ 로 블루베리 $1.07 \pm 0.12 \%$ 에 비해 높게 나타났으며, 조지방은 상동열매와 블루베리 모두 동일한 값 $(0.10 \pm 0.00 \%)$ 로 나타났다. 조회분의 경우에는 상동열매가 $0.50 \pm 0.10 \%$, 블루베리가 $0.20 \pm 0.00 \%$ 로 상동열매가 블루베리에 비해 조회분 함량이 2.5 배 높았으며, 탄수화물에서도 상동열매 가 $17.30 \pm 1.74 \%$, 블루베리가 $10.57 \pm 1.21 \%$ 으로 상동열매가 높 은 함량을 보였다. 열량은 상동열매가 $77.93 \pm 8.03 \mathrm{kcal} / 100 \mathrm{~g}$ 으 로 블루베리의 열량 $46.97 \pm 5.68 \mathrm{kcal} / 100 \mathrm{~g}$ 보다 1.7 배 정도 높 게 나타났다. Hyun 등(2015)은 상동열매의 수분 함량, 조단백 질, 조지방 및 조회분 함량을 각각 $75.04 \pm 0.01,2.01 \pm 0.48$, $0.84 \pm 0.02$ 및 $0.48 \pm 0.03 \%$ 로 보고한 바 있다. 이들 결과를 본 연구 결과와 비교했을 때 수분 함량과 조지방 함량에서 다소 차이가 있었으나 이는 수확시기의 차이에 기인한 것으로 사료 되며, 대체적으로 유사한 경향을 보였다. 따라서, 상동열매의 일 반성분은 블루베리에 비하여 수분함량이 적은 반면, 열량, 조단 백, 조회분, 탄수화물의 함량은 더 높음을 확인하였다.

블루베리 외에 상동열매와 비슷한 베리류에 속하는 블랙베리, 라즈베리, 딸기 및 체리의 일반성분을 비교한 연구 결과와 비 교했을 때(de Souza et al. 2014), 상동열매의 수분함량은 블랙 베리, 라즈베리, 딸기 및 체리(86.43-92.68\%)보다 낮았고, 조단 백질은 상동열매가 블랙베리 $(1.27 \pm 0.06 \%)$, 라즈베리 $(1.00 \pm$ $0.08 \%)$, 딸기 $(0.50 \pm 0.02 \%)$ 및 체리 $(1.00 \pm 0.05 \%)$ 보다 높은 함량 을 보였다. 한편, 조지방은 블랙베리 $(0.42 \pm 0.05 \%)$, 라즈베리 $(0.28 \pm 0.02 \%)$, 딸기 $(0.25 \pm 0.02 \%)$ 및 체리 $(0.20 \pm 0.01 \%)$ 보다 낮 았지만, 조회분 함량은 블랙베리 $(0.21 \pm 0.02 \%)$, 라즈베리 $(0.25 \pm$ $0.00 \%)$, 딸기 $(0.27 \pm 0.01 \%)$ 및 체리 $(0.42 \pm 0.01 \%)$ 보다 상동열매 의 함량이 높았다. 탄수화물의 경우 블랙베리, 라즈베리, 딸기 및 체리가 각각 $10.18 \pm 0.61,9.88 \pm 0.11,6.30 \pm 0.13,11.94 \pm$ $0.28 \%$ 로 상동열매가 이들에 비해 높은 함량을 나타냈다. 열량 은 상동열매가 블랙베리 $(49.57 \pm 2.18 \mathrm{kcal} / 100 \mathrm{~g})$, 라즈베리 $(46.00 \pm$ $0.85 \mathrm{kcal} / 100 \mathrm{~g})$, 딸기 $(29.40 \pm 0.75 \mathrm{kcal} / 100 \mathrm{~g})$ 및 체리 $(53.59 \pm$ $1.22 \mathrm{kcal} / 100 \mathrm{~g}$ )에 비해 $0.69-2.65$ 배 높았다. 이들 결과를 종합 해 볼 때 다른 베리류들에 비해 상동열매의 조단백, 조회분 및 탄수화물 함량이 상대적으로 높았으며 열량 또한 높은 것으로 확인되었다.

상동열매와 블루베리의 유리당 함량을 분석한 결과는 Table 2 와 같다. 총 당은 상동열매가 $9.85 \pm 0.56 \%$ 로 블루베리 $(5.33 \pm$ $0.80 \%$ )보다 약 2 배 정도 높은 것으로 확인되었다. 상동열매에 서는 fructose, glucose 및 maltose가 검출되었으며, 각각 $4.16 \pm$ $0.23,3.85 \pm 0.21,1.84 \pm 0.19 \%$ 를 함유하고 있는 것으로 분석되었
Table 2 Free sugar contents of $S$. thea and $V$. ashei fruit

\begin{tabular}{ccc}
\hline Free sugar $(\mathrm{g} / 100 \mathrm{~g})$ & S. thea & V. ashei \\
\hline Fructose & $4.16 \pm 0.23^{* 1)}$ & $2.82 \pm 0.67^{2}$ \\
Glucose & $3.85 \pm 0.21^{*}$ & $2.52 \pm 0.14$ \\
Sucrose & $\mathrm{ND}^{3)}$ & $\mathrm{ND}$ \\
Maltose & $1.84 \pm 0.19^{*}$ & $\mathrm{ND}$ \\
Total & $9.85 \pm 0.56$ & $5.33 \pm 0.80$
\end{tabular}

${ }^{1)}$ Means indicated significant difference in comparing with $S$. thea versus $V$. ashei at *p<0.05

${ }^{2)}$ Values are mean $\pm \mathrm{SD}(\mathrm{n}=3)$

${ }^{3)} \mathrm{ND}$ : Not detected

Table 3 Total polyphenol contents of the methanol extract and stepwise partitioned solvent fractions from $S$. thea and $V$. ashei fruit

\begin{tabular}{lcc}
\hline $\begin{array}{c}\text { Total polyphenol } \\
\left(\mathrm{mg} \mathrm{GAE}^{1)} / \mathrm{g}\right)\end{array}$ & S. thea & V. ashei \\
\hline Methanol extract & $6.30 \pm 0.83^{* 2)}$ & $2.85 \pm 1.20^{3)}$ \\
$n$-Hexane fraction & $6.42 \pm 1.95$ & $7.18 \pm 2.96$ \\
Chloroform fraction & $8.80 \pm 2.72$ & $11.01 \pm 1.08$ \\
Ethyl acetate fraction & $25.42 \pm 1.10^{*}$ & $31.25 \pm 0.95$ \\
$n$-Butanol fraction & $16.35 \pm 2.03$ & $14.75 \pm 1.15$ \\
Water fraction & $4.19 \pm 0.40^{*}$ & $1.13 \pm 0.09$ \\
\hline
\end{tabular}

${ }^{1)} \mathrm{GAE}$ : gallic acid equivalents

${ }^{2)}$ Means indicated significant difference in comparing with $S$. thea versus $V$. ashei at $* p<0.05$

${ }^{3)}$ Values are mean $\pm \mathrm{SD}(\mathrm{n}=3)$

고 sucrose는 검출되지 않았다. 블루베리의 유리당은 fructose가 $2.82 \pm 0.67 \%$, glucose가 $2.52 \pm 0.14 \%$ 로 분석되었으며, sucrose와 maltose는 검출되지 않았다. Cho 등(2010)은 lowbush 블루베리 와 highbush 블루베리의 fructose와 glucose함량을 각각 2.61$2.81 \%$ 와 $2.89-2.99 \%$ 로 보고한 바 있는데, 이는 본 연구에서의 블루베리의 유리당 함량과 유사한 것으로 확인되었다. 이상의 결과에서 나타낸 바와 같이 상동열매는 블루베리보다 유리당 함 량이 높아, 식품 제조 소재로서 활용가치가 높을 것으로 사료 된다.

\section{총 폴리페놀 함량}

식물계에 널리 존재하는 phytochemical 중 폴리페놀 화합물은 phenolic hydroxyl $(-\mathrm{OH})$ 기를 가지고 있어 이를 통해 인체에 유해한 활성산소를 제거하는 기능이 있는 것으로 알려져 있다 (Sato 등, 1996; Amarowicz 등, 2004). 이러한 폴리페놀 화합 물은 phenolic acid, flavonoid, anthocyanin, cinnamic acid, benzoic acid등이 있으며(Naczk와 Shahidi 2003), 각종 질병의 예방 및 치료에 효과가 있기 때문에 폴리페놀 함량이 높은 식 물은 건강보조식품 재료로 각광 받고 있다(Jang와 Yoon 2012). 본 연구에서는 상동열매와 블루베리의총 폴리페놀 함량을 비교 측정하기 위하여 각각 $80 \%$ 메탄올로 추출한 후, 헥산, 클로로 포름, 에틸아세테이트, 부탄올 및 물층으로 용매 분획 후 실험 에 사용하였다. Table 3에 나타낸 바와 같이 상동열매 메탄올 추출물의 폴리페놀 함량은 $6.30 \pm 0.83 \mathrm{mg} \mathrm{GAE} / \mathrm{g}$ 로 블루베리의 추출물 $(2.85 \pm 1.20 \mathrm{mg} \mathrm{GAE} / \mathrm{g})$ 에 비해 유의적으로 $(p<0.05)$ 높게 나타났다. 상동열매와 블루베리 용매 분획물의 총 폴리페놀 함 량은 에틸아세테이트 분획물이 각각 $25.42 \pm 1.10 \mathrm{mg} \mathrm{GAE} / \mathrm{g}$ 및 
Table 4 Total anthocyanin contents of the methanol extract and stepwise partitioned solvent fractions from $S$. thea and $V$. ashei fruit

\begin{tabular}{lcc}
\hline $\begin{array}{c}\text { Total anthocyanin } \\
\left(\mathrm{mg} \mathrm{CE}^{1)} / \mathrm{g}\right)\end{array}$ & $S$. thea & $V$. ashei \\
\hline Methanol extract & $37.34 \pm 4.34^{* 2)}$ & $15.56 \pm 2.67^{3)}$ \\
$n$-Hexane fraction & $\mathrm{ND}^{4)}$ & $51.66 \pm 11.46$ \\
Chloroform fraction & $13.98 \pm 1.95^{*}$ & $95.06 \pm 17.38$ \\
Ethyl acetate fraction & $\mathrm{ND}$ & $\mathrm{ND}$ \\
$n$-Butanol fraction & $163.2 \pm 33.38^{*}$ & $104.31 \pm 21.74$ \\
Water fraction & $4.57 \pm 2.57$ & $\mathrm{ND}$ \\
\hline
\end{tabular}

${ }^{1)} \mathrm{CE}$ : cyanidin-3-rutinoside equivalents

${ }^{2)}$ Means indicated significant difference in comparing with $S$. thea versus $V$. ashei at $* p<0.05$

${ }^{3)}$ Values are mean $\pm \mathrm{SD}(\mathrm{n}=3)$

${ }^{4)}$ ND: Not detected

$31.25 \pm 0.95 \mathrm{mg} \mathrm{GAE} / \mathrm{g}$ 로 용매 분획물들 중 가장 높았으며, 다 음으로 부탄올 분획물 $(16.35 \pm 2.03,14.75 \pm 1.15 \mathrm{mg} \mathrm{GAE} / \mathrm{g})$, 클로 로포름 분획물 $(8.80 \pm 2.72,11.01 \pm 1.08 \mathrm{mg} \mathrm{GAE} / \mathrm{g})$, 헥산 분획물 $(6.42 \pm 1.95,7.18 \pm 2.96 \mathrm{mg} \mathrm{GAE} / \mathrm{g})$, 물 분획물 $(4.19 \pm 0.40,1.13 \pm$ $0.09 \mathrm{mg} \mathrm{GAE} / \mathrm{g}$ ) 순으로 나타났다. Lee 등(2015)의 연구에서 $5 \%$ formic acid를 함유한 $50 \%$ 메탄올로 추출한 블랙라즈베리 와 라즈베리의 폴리페놀 함량이 $5.47 \mathrm{mg} \mathrm{GAE} / \mathrm{g}$ 와 $1.98 \mathrm{mg}$ $\mathrm{GAE} / \mathrm{g}$ 로 보고된 바 있으며, de Souza 등(2014)의 연구에서는 메탄올과 아세톤으로 추출한 블랙베리와 라즈베리, 딸기 및 체 리의 총 폴리페놀 함량이 각각 $8.81 \pm 4.77,3.58 \pm 7.06,6.22 \pm$ $15.51,3.14 \pm 5.95 \mathrm{mg} \mathrm{GAE} / \mathrm{g}$ 로 보고된 것과 비교했을 때 상동 열매 메탄올 추출물의 총 폴리페놀 함량은 다른 베리류 추출물 보다 비교적 높은 것을 확인할 수 있었다.

\section{총 안토시아닌 함량}

베리류를 포함한 여러 식물에 함유되어 있는 안토시아닌은 적 색, 자색 및 청색을 나타내는 flavonoid 색소이다(Francis 1989; Bridle와 Timberlake 1997). 안토시아닌의 phenolic 구조는 ROS (reactive oxygen species)를 소거함으로써 항산화 활성을 나타낸다고 알려져 있다(Wang와 Jiao 2000; Jang 등, 2014). 이에 따라 상동열매와 블루베리의 총 안토시아닌 함량을 cyanidin-3-rutinoside을 기준으로 측정한 결과, Table 4와 같이 상동열매 메탄올 추출물의 안토시아닌 함량은 $37.34 \pm 4.34 \mathrm{mg}$ $\mathrm{CE} / \mathrm{g}$ 로 블루베리 추출물의 $15.56 \pm 2.67 \mathrm{mg} \mathrm{CE} / \mathrm{g}$ 보다 유의적으 로 $(p<0.05)$ 높은 함량을 보였다. 상동열매의 용매 분획물에 대 한 안토시아닌 함량은 부탄올 분획물에서 $163.20 \pm 33.38 \mathrm{mg} \mathrm{CE} / \mathrm{g}$ 로 가장 높았고, 그 다음으로는 클로로포름 분획물이 $13.98 \pm 1.95$ $\mathrm{mg} \mathrm{CE} / \mathrm{g}$, 물 분획물이 $4.57 \pm 2.57 \mathrm{mg} \mathrm{CE} / \mathrm{g}$ 으로 나타났으며, 헥 산 분획물과 에틸아세테이트 분획물에서는 검출되지 않았다. 블 루베리의 경우 부탄올 분획물에서 $104.31 \pm 21.74 \mathrm{mg} \mathrm{CE} / \mathrm{g}$ 로 용 매 분획물들 중에서 가장 함량이 높았고, 클로로포름 분획물 $95.06 \pm 17.38 \mathrm{mg} \mathrm{CE} / \mathrm{g}$, 헥산 분획물 $51.66 \pm 11.46 \mathrm{mg} \mathrm{CE} / \mathrm{g}$ 의 순으로 나타내었으며, 에틸아세테이트 분획물과 물 분획물에서 는 검출되지 않았다. 따라서, 총 폴리페놀 함량과 더불어 항산 화 효능을 지닌 안토시아닌을 블루베리에 비해 많이 함유하고 있어, 상동열매는 천연 항산화제로서 이용가치가 높을 것으로 예상된다.

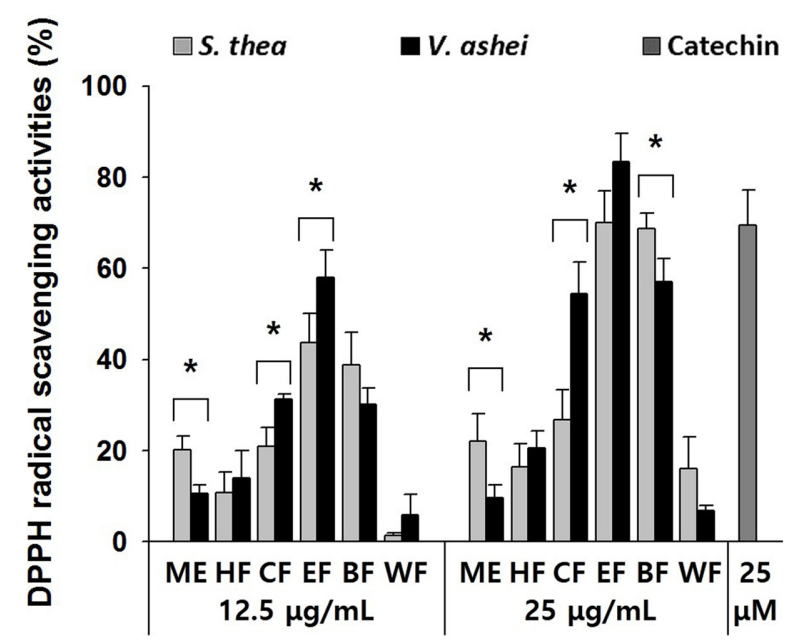

Fig. 1 DPPH radical scavenging activities of the methanol extract and stepwise partitioned solvent fractions from $S$. thea and $V$. ashei fruit. ME: $80 \%$ methanol extract, HF: $n$-hexane fraction, CF: chloroform fraction, $\mathrm{EF}$ : ethyl acetate fraction, BF: $n$-butanol fraction, WF: water fraction. Catechin was used as positive control. Values are mean $\pm \operatorname{SD}(n=3)$. Means indicated significant difference in comparing with $S$. thea versus V. ashei at $* p<0.05$

\section{자유라디칼 소거 활성}

생체 내에서 과도하게 발생한 자유라디칼은 DNA, 단백질, 세 포 분자들의 산화적 손상을 유발하여 다양한 질병을 일으키는 원인으로 작용하는데, 항산화제는 이러한 산화적 손상으로부터 신체를 방어하는 역할을 한다(Ames 등, 1993). DPPH 라디칼 은 항산화제, 방향족 아민류 등에 의해 환원되는 비교적 안정 한 자유라디칼로, 다양한 천연물의 항산화 활성을 탐색하는데 많이 이용되고 있다(Lee 등, 2005). 메탄올 추출물과 용매 분획 물의 $\mathrm{DPPH}$ 라디칼 소거 활성을 비교한 결과는 Fig. 1에 나타 낸 바와 같이 메탄올 추출물 $25 \mu \mathrm{g} / \mathrm{mL}$ 의 농도에서 상동열매 메 탄올 추출물의 $\mathrm{DPPH}$ 라디칼 소거능이 $22.18 \pm 5.96 \%$ 로 블루베 리 메탄올 추출물 $9.62 \pm 2.96 \%$ 에 비해 유의적으로 높게 나타났 다 $(p<0.05)$. 용매 분획물들 간의 $\mathrm{DPPH}$ 자유라디칼 소거 활성 은 상동열매와 블루베리가 유사한 경향을 보였으며, 에틸아세테 이트 분획물의 소거능이 각각 $70.09 \pm 6.96 \%$ 및 $83.47 \pm 6.15 \%$ 로 가장 높은 $\mathrm{DPPH}$ 자유라디칼 소거 활성을 나타냈다. 그 다음으 로 부탄올 분획물이 $68.65 \pm 3.39 \%$ 및 $57.05 \pm 5.17 \%$, 클로로포름 분획물이 $26.85 \pm 6.45 \%$ 및 $54.50 \pm 6.84 \%$, 헥산 분획물이 16.52 $\pm 5.02 \%$ 및 $20.65 \pm 3.73 \%$, 물 분획물이 $16.05 \pm 7.03 \%$ 및 6.79 $\pm 1.24 \%$ 의 순으로 나타났다.

Alkyl 라디칼은 hydrocarbon reaction에서 초기 반응 생성물 로 지질 과산화에 관여하기 때문에 alkyl 라디칼 소거 활성을 통해 항산화 효능을 확인 할 수 있다(Hyon 등, 2009). Alkyl 라디칼 소거 활성은 $\mathrm{DPPH}$ 라디칼 소거 활성과 비슷한 경향을 보였으며, 메탄올 추출물의 Alkyl 라디칼 소거 활성은 $40 \mu \mathrm{g} /$ $\mathrm{mL}$ 의 농도에서 상동열매가 $11.96 \pm 5.21 \%$, 블루베리가 $12.11 \pm$ $4.79 \%$ 로 나타났다(Fig. 2). $80 \mu \mathrm{g} / \mathrm{mL}$ 의 농도에서는 상동열매가 $19.55 \pm 9.55 \%$, 블루베리가 $15.45 \pm 9.77 \%$ 로 상동열매가 약간 높 았으나 유의적인 차이는 없었다. 상동열매와 블루베리 용매 분 획물의 alkyl 라디칼 소거 활성은 $40 \mu \mathrm{g} / \mathrm{mL}$ 의 농도에서 에틸아 


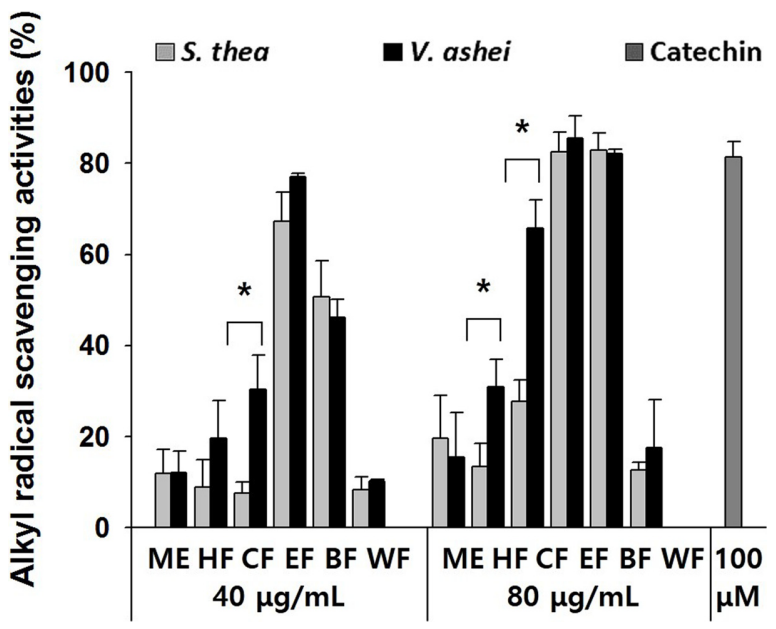

Fig. 2 Alkyl radical scavenging activities of the methanol extract and stepwise partitioned solvent fractions from $S$. thea and $V$. ashei fruit. ME: 80\% methanol extract, HF: $n$-hexane fraction, CF: chloroform fraction, $\mathrm{EF}$ : ethyl acetate fraction, $\mathrm{BF}$ : $n$-butanol fraction, WF: water fraction. Catechin was used as positive control. Values are mean $\pm \operatorname{SD}(n=3)$. Means indicated significant difference in comparing with $S$. thea versus V. ashei at $* p<0.05$

세테이트 분획물이 $67.16 \pm 6.41 \%$ 및 $77.08 \pm 0.75 \%$, 부탄올 분획 물이 $50.73 \pm 7.89 \%$ 및 $46.12 \pm 3.96 \%$, 클로로포름 분획물이 7.59 $\pm 2.48 \%$ 및 $30.43 \pm 7.48 \%$, 헥산 분획물이 $8.86 \pm 6.13 \%$ 및 19.64 $\pm 8.25 \%$, 물 분획물이 $8.26 \pm 2.98 \%$ 및 $10.25 \pm 0.25 \%$ 순으로 나타 났다.

$\mathrm{ABTS}$ 라디칼 소거 활성은 단시간에 측정할 수 있고, 친수성 뿐만 아니라 소수성 물질의 항산화 활성도 측정할 수 있기 때 문에 많이 사용되고 있는 방법이다(Awika 등, 2003). 상동열매 와 블루베리 메탄올 추출물과 용매 분획물의 $\mathrm{ABTS}$ 라디칼 소 거 활성은 Fig. 3에 나타낸 바와 같이 메탄올 추출물 $200 \mu \mathrm{g} /$ $\mathrm{mL}$ 농도에서 상동열매 메탄올 추출물의 $\mathrm{ABTS}$ 라디칼 소거 활 성은 $34.14 \pm 1.67 \%$ 로 블루베리 메탄올 추출물 $\mathrm{ABTS}$ 라디칼 소 거 활성 $21.70 \pm 1.63 \%$ 보다 유의적으로 $(p<0.05)$ 높게 나타났다. 상동열매의 용매 분획물 중에서는 부탄올 분획물이 $91.73 \pm 1.72 \%$ 로 가장 높은 $\mathrm{ABTS}$ 라디칼 소거 활성을 보였으며, 그 다음으 로 에틸아세테이트 분획물 $61.55 \pm 3.11 \%$, 클로로포름 분획물 $38.73 \pm 2.28 \%$, 헥산 분획물 $17.97 \pm 2.07 \%$, 물 분획물 $15.83 \pm$ $0.53 \%$ 순으로 나타났다. 블루베리 용매 분획물의 ABTS 라디 칼 소거 활성은 에틸아세테이트 분획물이 $89.61 \pm 2.74 \%$ 로 가장 높은 활성을 나타냈으며, 그 다음으로는 부탄올 분획물 $75.47 \pm$ $7.44 \%$, 클로로포름 분획물 $60.84 \pm 3.50 \%$, 헥산 분획물 $35.54 \pm$ $1.44 \%$, 물 분획물 $4.29 \pm 1.06 \%$ 순으로 나타났다. 상동열매 용매 분획물들 간 $\mathrm{ABTS}$ 라디칼 소거 활성 정도를 비교했을 때 $\mathrm{DPPH}$ 및 alkyl 라디칼 소거 활성과는 다소 다른 경향을 보였 다. 이는 자유라디칼인 $\mathrm{DPPH}$ 와 양이온 라디칼인 $\mathrm{ABTS}$ 에 결 합하는 폴리페놀 화합물의 종류가 다르기 때문에 분획물 종류 에 따른 라디칼 소거 활성 능력의 차이가 발생할 수 있을 것으 로 사료된다(Wang 등, 1998). 또한 ABTS 라디칼 소거 활성은 친수성 및 색소 물질을 함유하는 식물성 식품의 항산화 활성을 측정하는데 적합하며 넓은 범위의 $\mathrm{pH}$ 에서도 적용될 수 있는 방

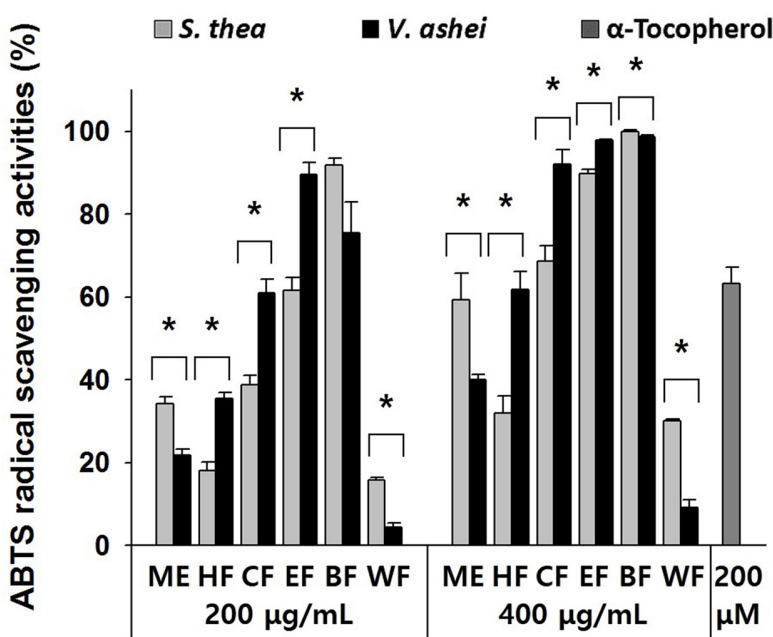

Fig. 3 ABTS radical scavenging activities of the methanol extract and stepwise partitioned solvent fractions from $S$. thea and $V$. ashei fruit. ME: $80 \%$ methanol extract, HF: $n$-hexane fraction, CF: chloroform fraction, EF: ethyl acetate fraction, BF: $n$-butanol fraction, WF: water fraction. $\alpha$ tocopherol was used as positive control. Values are mean $\pm \mathrm{SD}(n=3)$.

*Means indicated significant difference in comparing with $S$. thea versus $V$. ashei at $p<0.05$

법이므로(Lemañska 등, 2001; Floegel 등, 2011), 상동열매 부 탄올 분획물의 경우 에틸아세테이트 분획물에 비해 폴리페놀 함 량은 낮지만 안토시아닌 함량이 높고, 안토시아닌은 낮은 $\mathrm{pH}$ 에 서 안정하기 때문에 $\mathrm{DPPH}$ 및 alkyl 라디칼 소거 활성 측정 시 보다 $\mathrm{ABTS}$ 소거 활성 측정 시 부탄올 분획물이 상대적으로 더 우수한 활성을 나타내는 것으로 사료된다(Abdel-Aal와 Hucl 2003).

\section{산화적 스트레스로부터의 세포 보호 활성}

Human dermal fibroblast 세포의 증식에 미치는 영향을 확인하 기 위해 상동열매와 블루베리 메탄올 추출물 및 용매 분획물을 각각 $100 \mu \mathrm{g} / \mathrm{mL}$ 처리 하고 MTT assay를 수행한 결과, 메탄올 추출물과 대부분의 용매 분획물 처리에 의한 세포 생존율은 92.92-103.52\%로 세포 독성이 거의 관찰되지 않았다(Fig 4A). 한편, 헥산 분획물의 경우에는 상동열매의 세포 생존율이 92.44 $\pm 4.00 \%$, 블루베리의 세포 생존율이 $61.08 \pm 7.42 \%$ 로 블루베리 헥산 분획물에서 세포 독성이 확인되었다. 블루베리의 헥산 분 획물을 제외한 모든 용매 분획물들과 메탄올 추출물에 의한 세 포 독성이 관찰되지 않음에 따라, $\mathrm{H}_{2} \mathrm{O}_{2}$ 로 유도된 산화적 스트 레스에 대한 세포 보호 효과를 측정하였다(Fig. 4B). Fibroblast 세포에 $200 \mu \mathrm{M}$ 농도의 $\mathrm{H}_{2} \mathrm{O}_{2}$ 를 처리한 결과 세포 생존율이 $49.52 \pm 4.11 \%$ 로 감소하는 것을 확인하였으며, 상동열매와 블루 베리 메탄올 추출물 $100 \mu \mathrm{g} / \mathrm{mL}$ 각각을 $200 \mu \mathrm{M}$ 농도의 $\mathrm{H}_{2} \mathrm{O}_{2}$ 와 함께 동시 처리했을 경우에는 세포 생존율이 $64.64 \pm 8.98 \%$ 및 $63.53 \pm 8.83 \%$ 로, $\mathrm{H}_{2} \mathrm{O}_{2}$ 단독 처리에 비해 15.11 및 $14.01 \%$ 의 세포 보호 효과를 확인하였다 $(p<0.05)$. 에틸아세테이트 분획물 과 $\mathrm{H}_{2} \mathrm{O}_{2}$ 를 동시 처리한 경우에는 상동열매와 블루베리가 각각 $58.41 \pm 6.99$ 와 $56.07 \pm 8.15 \%$ 의 세포 생존율을 나타내어 각각 8.89 와 $6.54 \%$ 의 세포 보호 효과를 확인하였다. 부탄올 분획물 

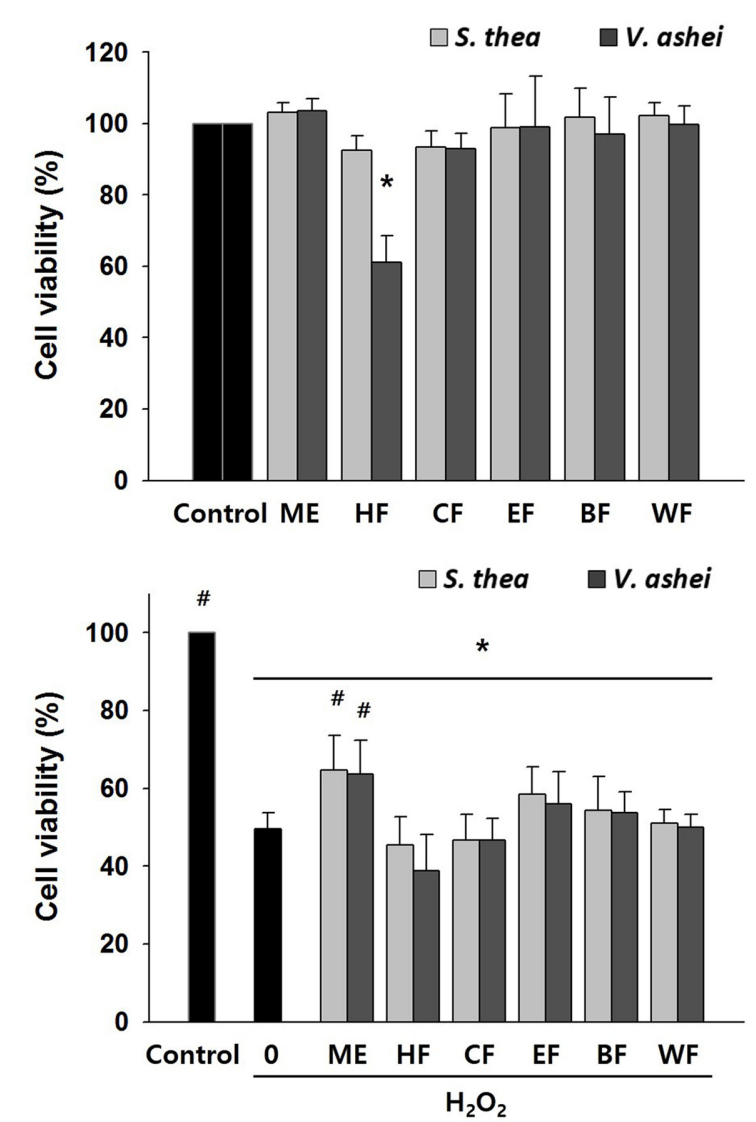

Fig. 4 Protective effects of the methanol extract and stepwise partitioned solvent fractions from $S$. thea and $V$. ashei fruit on $\mathrm{H}_{2} \mathrm{O}_{2}$-indeced cytotoxicity. (A) Dermal fibroblast cells were treated for $4 \mathrm{~h}$ with indicated samples. (B) Dermal fibroblast cells were co-treated for $4 \mathrm{~h}$ with indicated samples and $\mathrm{H}_{2} \mathrm{O}_{2}(200 \mu \mathrm{M})$. ME: $80 \%$ methanol extract, $\mathrm{HF}$ : $n$-hexane fraction, $\mathrm{CF}$ : chloroform fraction, EF: ethyl acetate fraction, BF: $n$-butanol fraction, WF: water fraction. Values are mean $\pm \mathrm{SD}(\mathrm{n}=3)$. Means indicated significant difference in comparing with $S$. thea versus $V$. ashei at $* p<0.05$ and in comparing $\mathrm{H}_{2} \mathrm{O}_{2}$ at ${ }^{\#} p<0.05$

의 세포 생존율은 상동열매와 블루베리가 각각 $54.34 \pm 8.60$ 와 $53.74 \pm 5.27 \%$ 로 나타나 세포 보호 효과가 미미함을 확인하였다. 물 분획물에서는 세포 보호 효과가 없었으며, 헥산 분획물과 클 로로포름 분획물에서는 오히려 세포 생존율이 감소하였다. 따라 서, $\mathrm{H}_{2} \mathrm{O}_{2}$ 로 유도된 산화적 스트레스로부터 세포 보호 효과는 그 차이가 크지 않지만 상동열매가 블루베리보다 우수한 것으 로 나타났으며, 특히 메탄올 추출물과 에틸아세테이트 분획물이 상대적으로 다른 분획물에 비해 우수한 세포 보호 효과를 보였다.

\section{암세포 중식 억제 활성}

암세포의 증식에 미치는 영향을 확인하기 위해 $\mathrm{AGS}$ 와 MDA$\mathrm{MB}-231$ 세포에 상동열매와 블루베리 메탄올 추출물과 용매 분 획물을 48시간동안 처리한 후 MTT assay를 실시하였다. Fig. 5 에서 나타낸 바와 같이, 상동열매와 블루베리의 헥산 분획물과 클로로포름 분획물에서 AGS와 MDA-MB-231 암세포에 대해 증식 억제 활성이 나타났다. 인체 위암세포주인 $\mathrm{AGS}$ 의 경우, $200 \mu \mathrm{g} / \mathrm{mL}$ 상동열매 헥산 분획물이 $75.08 \pm 1.78 \%$, 클로로포름
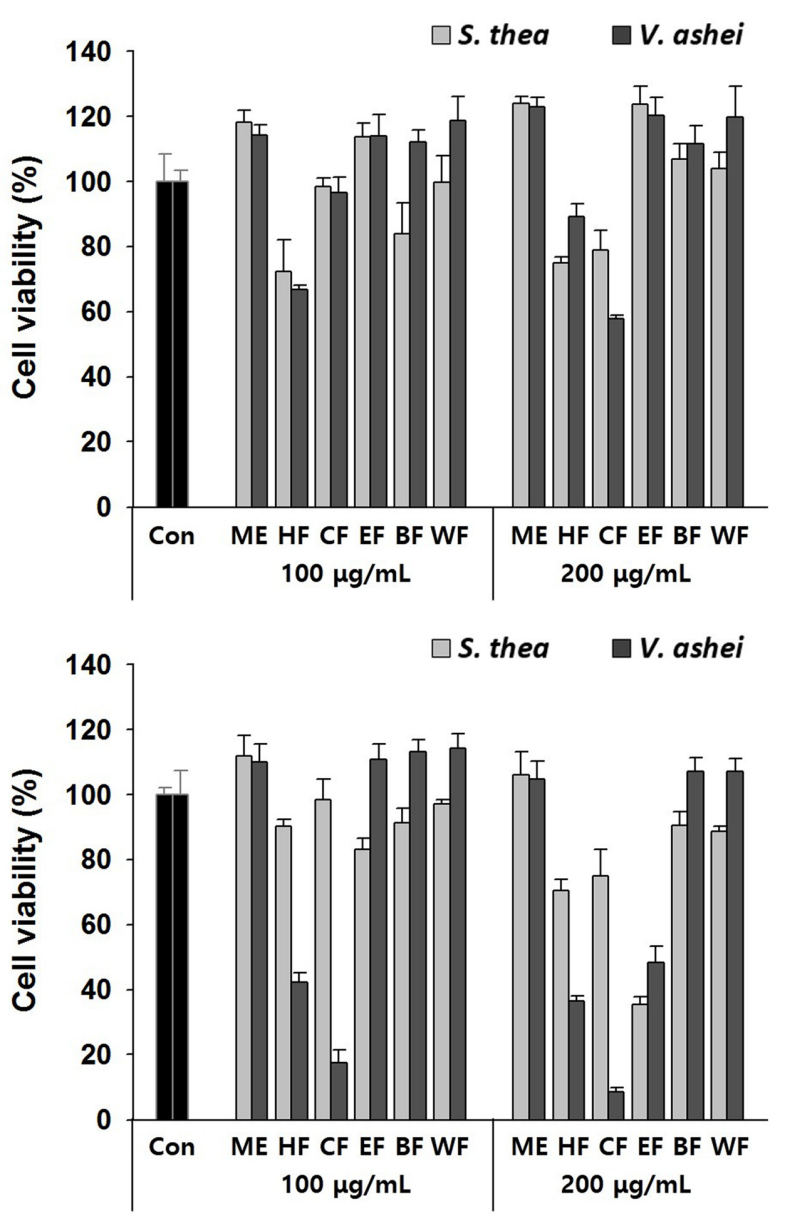

Fig. 5 Effects of the methanol extract and stepwise partitioned solvent fractions from $S$. thea and $V$. ashei fruit on the viability of AGS and MDA-MB-231 cells. Cell viabilities were determined for $48 \mathrm{~h}$ with indicated concentrations of methanol extracts and its fractions in AGS (A) and MDA-MB-231 cells (B). Each value is expressed as mean \pm SD $(n=3)$

분획물이 $78.77 \pm 6.15 \%$ 의 세포생존율을 나타났으며, 블루베리 헥산 분획물은 $89.12 \pm 3.98 \%$, 클로로포름 분획물은 $57.77 \pm 1.05 \%$ 의 세포생존율을 나타냈다(Fig. 5A). 인체 유방암 세포주 MDA$\mathrm{MB}-231$ 에서는 상동열매 헥산 분획물이 $70.35 \pm 3.51 \%$, 클로로포 름 분획물이 $75.04 \pm 7.96 \%$ 의 세포생존율을 나타냈으며, 에틸아 세테이트 분획물의 경우에도 $35.42 \pm 2.44 \%$ 의 세포생존율이 나 타났다. 이에 비해 블루베리의 헥산 분획물은 $36.50 \pm 1.60 \%$, 클 로로포름 분획물은 $8.54 \pm 1.25 \%$, 에틸아세테이트 분획물은 48.34 $\pm 4.91 \%$ 의 MDA-MB-231 세포생존율을 나타냈다(Fig. 5B). Adams 등(2010)은 블루베리 메탄올 추출물이 MDA-MB-231 세포에서 $\mathrm{PI} 3 \mathrm{~K} / \mathrm{Akt}$ pathway의 감소와 NF- $\mathrm{KB}$ 의 활성화를 통해 apoptosis를 유발한다고 보고하였으며, Pan 등(2007)은 블루베리 활성 성분 중 pterostilbene이 AGS 세포에서 p53 발현의 증가 를 통한 cell cycle arrest와 apoptosis 유도에 대해 보고한 바 있다. 따라서, 상동열매에 의한 암세포의 apoptosis 유발 가능성 에 대해서도 연구가 필요하며 이를 통해 위암과 유방암을 타겟 하는 항암식품 소재 개발에 기여할 수 있을 것으로 사료된다. 


\section{GC-MS를 이용한 성분 분석}

상동열매와 블루베리 메탄올 추출물 및 용매 분획물의 성분조 성을 GC-MS를 이용하여 분석한 결과는 Table 5 에 나타내었다. 메탄올 추출물의 경우 상동열매와 블루베리가 유사한 성분조성 을 가지는 것으로 확인되었으며, 항산화 활성이 보고된 바 있 는 3,5-dihydroxy-6-methyl-2,3-dihydro-4H-pyran-4-one (상동열 매 $32.75 \%$ 및 블루베리 $27.44 \%$ )와 catechol (상동열매 $2.73 \%$ 및 블루베리 $2.17 \%$ )이 상당량 검출되었다(Yang 등, 2007 ;
Čechovská 등, 2011; Yu 등, 2013). 용매 분획물들 중에서는 폴리페놀 함량과 자유라디칼 소거 활성이 우수했던 에틸아세테 이트 분획물과 부탄올 분획물에서 다른 분획물들에 비해 다양 한 종류의 항산화 활성을 가지는 성분들이 검출되었다. 상동열 매 에틸아세테이트 분획물에서는 항산화 활성이 보고된 3,5dihydroxy-6-methyl-2,3-dihydro-4H-pyran-4-one (4.51\%), benzoic acid (1.07\%), catechol (7.31\%), salicylic acid (1.61\%), syringol (2.48\%) 및 pyrogallol $(8.05 \%)$ 가, 부탄올 분획물에서는 3,5-

Table 5 Compounds identified of the methanol extract and stepwise partitioned solvent fractions from $S$. thea and $V$. ashei fruit by GC-MS

\begin{tabular}{|c|c|c|c|c|c|c|c|c|c|c|c|c|c|c|}
\hline \multirow{3}{*}{ No } & \multirow{3}{*}{$\begin{array}{l}\mathrm{RT}^{1)} \\
(\min )\end{array}$} & \multirow{3}{*}{ Compound $^{2)}$} & \multicolumn{12}{|c|}{$\operatorname{Area}^{3)}(\%)$} \\
\hline & & & \multicolumn{6}{|c|}{ S. thea } & \multicolumn{6}{|c|}{ V. ashei } \\
\hline & & & $\mathrm{ME}^{4)}$ & $\mathrm{HF}$ & $\mathrm{CF}$ & $\mathrm{EF}$ & $\mathrm{BF}$ & WF & ME & $\mathrm{HF}$ & $\mathrm{CF}$ & EF & $\mathrm{BF}$ & WF \\
\hline 1 & 5.043 & N,N-Bis(2-ethylbutyl)amine & - & - & - & - & - & 1.11 & - & - & - & - & - & - \\
\hline 2 & 5.046 & 4,5-Dimethyl-1,3-dioxol-2-one & - & - & - & - & - & - & - & - & - & - & - & 3.53 \\
\hline 3 & 5.278 & Furaneol & 4.69 & - & - & - & 5.95 & 3.65 & 3.42 & - & - & - & - & 5.82 \\
\hline 4 & 5.721 & Thymine & - & - & - & 1.75 & 15.98 & 16.87 & - & - & - & - & 11.66 & 20.91 \\
\hline 5 & 5.765 & Mono-methyl succinate & - & - & 1.04 & 16.74 & - & - & - & - & - & 1.55 & - & - \\
\hline 6 & 5.766 & $\begin{array}{l}\text { 4a,4b-Dimethylhexahydropyrimido }\left[5^{\prime}, 4^{\prime}: 3,4\right] \text { cyclobuta } \\
{[1,2-\mathrm{d}] \text { pyrimidine- } 2,4,5,7(3 \mathrm{H}, 6 \mathrm{H}) \text {-tetrone }}\end{array}$ & 24.08 & - & - & - & - & - & 19.99 & - & - & - & - & - \\
\hline 7 & 5.885 & Guaiacol & - & - & - & 0.69 & - & - & - & - & - & 0.81 & - & - \\
\hline 8 & 6.236 & Dimethyl malate & - & - & 8.91 & - & - & - & - & - & - & - & - & - \\
\hline 9 & 6.922 & N-Nitrosodiethylamine & 5.13 & - & - & - & 5.56 & 5.63 & 4.63 & - & - & - & - & 7.98 \\
\hline 10 & 7.126 & 3,5-Dihydroxy-6-methyl-2,3-dihydro-4H-pyran-4-one & 32.75 & - & - & 4.51 & 37.71 & 31.02 & 27.44 & - & - & - & 56.26 & 41.96 \\
\hline 11 & 7.475 & Benzoic acid, ammonium salt & - & - & - & - & - & - & - & - & - & - & 2.98 & - \\
\hline 12 & 7.495 & Benzoic acid & - & - & - & 1.07 & - & - & - & - & - & 4.75 & - & - \\
\hline 13 & 7.985 & 5-Hydroxymaltol & - & - & - & - & - & 3.40 & 4.04 & - & - & 2.34 & 9.40 & - \\
\hline 14 & 8.100 & 5,5-Dimethyl-2,4-hexanedione & - & - & - & - & - & - & - & - & - & - & - & 5.86 \\
\hline 15 & 8.304 & Catechol & 2.73 & - & - & 7.31 & 2.57 & 2.33 & 2.17 & - & - & 9.11 & 6.19 & 3.24 \\
\hline 16 & 8.753 & 4-Methylbenzaldehyde & - & - & - & 16.12 & - & - & - & - & - & 7.86 & - & - \\
\hline 17 & 8.972 & Dimethyl 2-oxopentanedioate & - & - & - & 16.30 & - & - & - & - & - & - & - & - \\
\hline 18 & 9.071 & 1-Ethyl-2-hydroxymethylimidazole & 20.99 & - & - & - & 28.72 & 34.60 & 33.27 & - & - & - & - & - \\
\hline 19 & 9.092 & 5-(Hydroxymethyl)-2-furaldehyde & - & - & - & - & - & - & - & - & - & - & - & 8.68 \\
\hline 20 & 9.776 & Dimethyl 2-propoxysuccinate & - & - & - & 2.65 & 3.51 & - & - & - & - & - & - & - \\
\hline 21 & 10.015 & 3-Methoxycatechol & - & - & - & 2.90 & - & - & - & - & - & 6.32 & - & - \\
\hline 22 & 10.063 & 2-Methoxyhydroquinone & - & - & - & - & - & - & - & - & - & - & 1.58 & - \\
\hline 23 & 11.270 & Salicylic acid & - & - & - & 1.61 & - & - & - & - & - & - & - & - \\
\hline 24 & 11.322 & 2-Methoxy-4-vinylphenol & - & - & - & 5.52 & - & - & - & - & 18.29 & 16.48 & - & - \\
\hline 25 & 12.401 & Syringol & - & - & - & 2.48 & - & - & - & - & 21.94 & 11.90 & 2.63 & - \\
\hline 26 & 12.775 & Linalool & - & - & - & - & - & - & - & - & - & 1.66 & - & - \\
\hline 27 & 13.730 & Pyrogallol & - & - & - & 8.05 & - & - & - & - & - & - & - & - \\
\hline 28 & 15.215 & 2-Hydroxy-6-methylbenzaldehyde & - & - & - & - & - & - & - & - & - & 15.29 & - & - \\
\hline 29 & 15.964 & Trimethyl citrate & - & - & - & 0.50 & - & - & - & - & - & - & - & - \\
\hline 30 & 17.281 & 2,6-Di-tert-butylphenol & - & - & - & - & - & 1.39 & - & - & - & - & - & 2.02 \\
\hline 31 & 18.894 & 3,4-Dimethoxyacetophenone & - & - & 3.91 & - & - & - & - & - & - & - & - & - \\
\hline 32 & 19.081 & Vanillic acid & - & - & - & - & - & - & - & - & - & 6.72 & - & - \\
\hline 33 & 21.017 & 5-Methyl[1,5]thiazocane & - & - & - & - & - & - & - & - & - & - & 9.30 & - \\
\hline 34 & 21.725 & Syringaldehyde & - & - & - & - & - & - & - & - & 3.00 & - & - & - \\
\hline 35 & 24.782 & Methyl syringate & - & - & - & - & - & - & - & - & 13.53 & 2.31 & - & - \\
\hline 36 & 25.286 & Pluchidiol & - & - & - & - & - & - & - & - & 3.89 & 1.19 & - & - \\
\hline 37 & 26.189 & Syringic acid & - & - & - & - & - & - & - & - & - & 7.88 & - & - \\
\hline 38 & 28.229 & Zierone & - & - & - & - & - & - & - & - & - & 2.91 & - & - \\
\hline 39 & 28.739 & Methyl palmitate & - & 10.54 & 11.00 & 1.24 & - & - & - & 3.48 & 1.25 & - & - & - \\
\hline 40 & 28.901 & 1,4-Diaza-2,5-dioxo-3-isobutyl bicyclo[4.3.0]nonane & - & - & 1.35 & - & - & - & - & - & - & - & - & - \\
\hline
\end{tabular}


Table 5 Compounds identified of the methanol extract and stepwise partitioned solvent fractions from $S$. thea and $V$. ashei fruit by GC-MS

\begin{tabular}{|c|c|c|c|c|c|c|c|c|c|c|c|c|c|}
\hline \multirow{3}{*}{ No } & \multirow{3}{*}{$\begin{array}{l}\mathrm{RT}^{1)} \\
(\min )\end{array}$} & \multicolumn{12}{|c|}{ Area $^{3)}(\%)$} \\
\hline & & \multicolumn{6}{|c|}{ S. thea } & \multicolumn{6}{|c|}{ V. ashei } \\
\hline & & $\mathrm{ME}^{4)}$ & $\mathrm{HF}$ & $\mathrm{CF}$ & $\mathrm{EF}$ & $\mathrm{BF}$ & WF & $\mathrm{ME}$ & $\mathrm{HF}$ & $\mathrm{CF}$ & $\mathrm{EF}$ & $\mathrm{BF}$ & WF \\
\hline 41 & 29.638 Palmitic acid & - & - & - & - & - & - & 1.70 & - & - & - & - & - \\
\hline 42 & 29.742 Methyl glycol phthalate & - & - & - & - & - & - & - & - & - & 0.92 & - & - \\
\hline 43 & 31.254 Methyl heptadecanoate & - & 0.27 & - & - & - & - & - & - & - & - & - & - \\
\hline 44 & 31.753 Methyl 2-hydroxyhexadecanoate & - & 1.04 & 1.85 & - & - & - & - & - & - & - & - & - \\
\hline 45 & 32.910 Methyl linoleate & - & 22.58 & 24.21 & 2.02 & - & - & - & 9.99 & 2.52 & - & - & - \\
\hline 46 & 32.915 methyl octadeca-8,11-dienoate & - & - & - & - & - & - & 1.42 & - & - & - & - & - \\
\hline 47 & 33.070 Methyl linolenate & - & 23.26 & 27.77 & 2.55 & - & - & 0.98 & 7.61 & - & - & - & - \\
\hline 48 & 33.178 Methyl oleate & - & 0.78 & - & - & - & - & - & 0.52 & - & - & - & - \\
\hline 49 & 33.345 Phytol & - & 1.91 & 1.39 & - & - & - & - & 0.92 & - & - & - & - \\
\hline 50 & 33.646 Methyl stearate & - & 4.24 & 3.08 & - & - & - & - & 0.82 & - & - & - & - \\
\hline 51 & 33.817 Ethyl linoleate & - & 5.00 & - & - & - & - & 0.94 & 0.99 & - & - & - & - \\
\hline 52 & 38.152 Methyl eicosanoate & - & 0.71 & - & - & - & - & - & 0.58 & - & - & - & - \\
\hline 53 & 41.547 Octadecan-1-ol & - & 0.54 & - & - & - & - & - & - & - & - & - & - \\
\hline 54 & 41.942 2-Palmitoylglycerol & - & 1.89 & - & - & - & - & - & - & - & - & - & - \\
\hline 55 & $\begin{array}{l}42.465 \text { N-(2,6-Dimethylphenyl)-2-(4-morpholinyl)-2- } \\
\text { phenyl-N-(phenylacetyl)acetamide }\end{array}$ & - & - & - & - & - & - & - & - & 3.47 & - & - & - \\
\hline 56 & 42.745 Mono(2-ethylhexyl)phthalate & - & - & - & - & - & - & - & 0.76 & - & - & - & - \\
\hline 57 & 42.751 Bis(2-ethylhexyl) phthalate & - & - & 0.49 & - & - & - & - & - & 1.94 & - & - & - \\
\hline 58 & 42.769 Dioctyl phthalate & - & - & - & 5.99 & - & - & - & - & - & - & - & - \\
\hline 59 & 45.440 1-Monolinolein & - & 9.93 & 2.34 & - & - & - & - & 1.51 & - & - & - & - \\
\hline 60 & 48.006 Squalene & - & - & - & - & - & - & - & 1.73 & - & - & - & - \\
\hline 61 & $51.984 \beta$-Tocopherol & - & 0.82 & - & - & - & - & - & 2.01 & - & - & - & - \\
\hline 62 & $56.525 \beta$-Sitosterol & - & 16.49 & 12.66 & - & - & - & - & 35.83 & 19.50 & - & - & - \\
\hline 63 & 57.265 Methyl commate D & 9.63 & - & - & - & - & - & - & 11.79 & 10.67 & - & - & - \\
\hline \multirow[t]{2}{*}{64} & 58.114 Methyl commate B & - & - & - & - & - & - & - & 21.46 & - & - & - & - \\
\hline & Total & 100 & 100 & 100 & 100 & 100 & 100 & 100 & 10 & 100 & 100 & 100 & 100 \\
\hline
\end{tabular}

${ }^{1)}$ Retention time

${ }^{2)}$ Compounds were tentatively identified based on parent molecular ions, retention times, retention indices, and elution order, as well as the fragmentation spectra compared with the literature

${ }^{3)}$ Peak area relative to total peak area\%

${ }^{4)} \mathrm{ME}$ : $80 \%$ methanol extract, HF: $n$-hexane fraction, CF: chloroform fraction, EF: ethyl acetate fraction, BF: $n$-butanol fraction, WF: water fraction

dihydroxy-6-methyl-2,3-dihydro-4H-pyran-4-one (37.71\%)와 catechol (2.57\%)이 확인되었다(Loo 등, 2008; Velika와 Kron, 2012; Wang 등, 2015; Ozturk Sarikaya 2015). 블루베리 에틸아세테 이트 분획물에서 검출된 화합물들 중에서는 benzoic acid (4.75\%), catechol (9.11\%), syringol (11.90\%), linalool (1.66\%), vanillic acid $(6.72 \%)$, methyl syringate $(2.31 \%)$ 및 syringic acid $(7.88 \%$ )가, 부탄올 분획물에서는 3,5-dihydroxy-6-methyl2,3-dihydro-4H-pyran-4-one (56.26\%), catechol (6.19\%) 및 syringol $(2.63 \%)$ 가 항산화 활성을 나타내는 것으로 보고된 바 있다(Kumar 등, 2011; Jubri 등, 2013; Cikman 등, 2015; Seol 등, 2016). 한편. 폴리페놀과 안토시아닌의 함량과 자유라 디칼 소거 활성이 상대적으로 높지 않았지만 세포 보호 효과가 높았던 메탄올 추출물에서는 4a,4b-dimethylhexahydropyrimido [5',4':3,4]cyclobuta[1,2-d]pyrimidine-2,4,5,7(3H,6H)-tetrone가 상 동열매와 블루베리에 각각 24.08 및 $19.99 \%$ 로 상대적으로 함량 이 높게 나타났다. 이 화합물은 다른 용매 분획물에서는 검출 되지 않는 것으로 확인된 바 메탄올 추출물의 $\mathrm{H}_{2} \mathrm{O}_{2}$ 로 유도된 산화적 스트레스에 대한 세포 보호 효과에 기여할 수 있을 것
으로 판단되며, 자유라디칼 소거 활성과 세포 보호 효과에 대 한 추가적인 연구가 필요하다고 사료된다. 위암과 유방암 세포 의 증식 억제 활성이 있었던 헥산 분획물과 클로로포름 분획물 의 경우 다양한 암세포에 대한 항암활성을 가지는 것으로 알려 진 $\beta$-sitosterol이 상동열매 헥산 분획물과 클로로포름 분획물에 서 각각 16.49 와 $35.83 \%$, 블루베리 헥산 분획물과 클로로포름 분획물에서는 각각 12.66 와 $19.50 \%$ 로 확인되었으며(Bin Sayeed 와 Ameen 2015), 다른 분획물에서는 검출되지 않았다. 이러한 결과들을 토대로 상동열매는 천연 항산화 및 항암 소재 로서의 활용가치가 증대될 것으로 사료된다.

\section{초 록}

본 연구에서는 블루베리의 형태 및 풍미와 유사한 상동열매의 일반성분과 항산화 활성을 비교하였다. 열량, 조단백, 조회분, 탄수화물 및 유리당은 상동열매가 블루베리에 비해 더 높았으 며 수분은 블루베리가 더 높은 것으로 나타났다. 상동열매의 주 
요 유리당은 fructose, glucose 및 maltose로 나타난 반면, 블루 베리에서는 maltose가 검출되지 않았다. 상동열매와 블루베리를 각각 $80 \%$ 메탄올로 추출한 후, 헥산, 클로로포름, 에틸아세테 이트, 부탄올 및 물층으로 용매 분획하여 이들의 폴리페놀 및 안토시아닌 함량과 항산화 활성을 비교하였다. 상동열매 메탄올 추출물이 블루베리 메탄올 추출보다 폴리페놀 함량과 안토시아 닌 함량 모두 높게 나타났으며, 아울러 DPPH, alkyl, 및 ABTS 라디칼 소거 활성 또한 더 우수하였다. 용매 분획물들을 대상 으로 항산화 효능을 비교했을 때, 상동열매와 블루베리 모두 폴 리페놀 함량이 상대적으로 높았던 에틸아세테이트 분획물의 $\mathrm{DPPH}$ 와 alkyl radical 소거 활성이 가장 우수했으며, 안토시아 닌 함량이 높은 부탄올 분획물의 ABTS radical 소거 활성이 상 대적으로 우수하였다. 특히, 안토시아닌 함량이 상대적으로 높 았던 상동열매 부탄올 분획물의 $\mathrm{ABTS}$ 라디칼 소거 활성은 블 루베리 부탄올 분획물에 비해 상대적으로 우수하였다. 상동열매 와 블루베리 메탄올 추출물은 피부세포에서의 $\mathrm{H}_{2} \mathrm{O}_{2}$ 로 유도된 산화적 스트레스로부터 세포 보호 효과를 나타냈으며, 블루베리 와 비교하여 상동열매에서 그 효능이 더 우수한 것으로 나타났 다. 또한 상동열매와 블루베리의 헥산 분획물과 클로로포름 분 획물이 위암(AGS)와 유방암(MDA-MB-231)세포에 대한 증식 억제 활성이 확인되었다. 본 연구에서는 최초로 상동열매와 블 루베리의 일반성분, 항산화 및 항암 활성을 비교하였으며, 상동 열매가 블루베리보다 상대적으로 높은 함량의 폴리페놀과 안토 시아닌을 함유할 뿐만 아니라 블루베리보다 우수하거나 그에 필 적한 항산화 및 항암 활성을 나타내고 있어, 항산화 식품 및 천 연 항산화 소재 로서의 활용가치가 클 것으로 사료된다.

Keywords 블루베리 · 상동열매 · 일반성분 - 항산화 · 항증식

Acknowledgments This research was supported by the 2016 scientific promotion program funded by Jeju National University.

\section{References}

Abdel-Aal E-SM, Hucl P (2003) Composition and stability of anthocyanins in blue-grained wheat. J Agric food Chem 51: 2174-2180

Adams LS, Phung S, Yee N, Seeram NP, Li L, Chen S (2010) Blueberry phytochemicals inhibit growth and metastatic potential of MDA-MB-231 breast cancer cells through modulation of the phosphatidylinositol 3kinase pathway. Cancer Res 70: 3594-3605

Amarowicz R, Pegg RB, Rahimi-Moghaddam P, Barl B, Weil JA (2004) Free-radical scavenging capacity and antioxidant activity of selected plant species from the Canadian prairies. Food Chem 84: 551-562

Ames BN, Shigenaga MK, Hagen TM (1993) Oxidants, antioxidants, and the degenerative diseases of aging. Proc Nati Acad Sci USA 90: 7915-7922

An YH, Lee IS, Kim HS (2015) Quality Characteristics of Sikhye made with Berries. Korean J Food Cook Sci 27: 803-814

Awika JM, Rooney LW, Wu X, Prior RL, Cisneros-Zevallos L (2003) Screening methods to measure antioxidant activity of sorghum (Sorghum bicolor) and sorghum products. J Agric Food Chem 51: 6657-6662

Bin Sayeed MS, Ameen SS (2015) Beta-sitosterol: a promising but orphan nutraceutical to fight against cancer. Nutr Cancer 67: 1216-1222

Bridle P, Timberlake C (1997) Anthocyanins as natural food colours-selected aspects. Food Chem 58: 103-109

Carmichael J, DeGraff WG, Gazdar AF, Minna JD, Mitchell JB (1987) Evaluation of a tetrazolium-based semiautomated colorimetric assay: assessment of chemosensitivity testing. Cancer Res 47: 936-942

Čechovská L, Cejpek K, Konečný M, Velíšek J (2011) On the role of 2,3dihydro-3,5-dihydroxy-6-methyl-(4H)-pyran-4-one in antioxidant capacity of prunes, Eur Food Res Technol 233:367-376

Cheung LM, Cheung PCK, Ooi VEC (2003) Antioxidant activity and total phenolics of edible mushroom extracts. Food Chem 81: 249-255

Cho WJ, Song BS, Lee JY, Kim JK, Kim JH, Yoon YH, Choi JI, Kim GS, Lee JW (2010) Composition Analysis of Various Blueberries Produced in Korea and Manufacture of Blueberry Jam by Response Surface Methodology J Korean Soc Food Sci Nutr

Chung HJ (2015) Comparative study of antioxidant activity of imported tropical and subtropical fruits. Korean J Food Preserv 22: 577-584

Chung SK, Chen CYO, Blumberg JB (2009) Flavonoid-rich fraction from Sageretia theezans leaves scavenges reactive oxygen radical species and increases the resistance of low-density lipoprotein to oxidation. J Med Food 12: 1310-1315

Chung SK, Kim YC, Takaya Y, Terashima K, Niwa M (2004) Novel flavonol glycoside, 7-O-methyl mearnsitrin, from Sageretia theezans and its antioxidant effect. J Agric Food Chem 52: 4664-4668

Cikman O, Soylemez O, Ozkan OF, Kiraz HA, Sayar I, Ademoglu S, Taysi S, Karaayvaz M (2015) Antioxidant Activity of Syringic Acid Prevents Oxidative Stress in 1-arginine-Induced Acute Pancreatitis: An Experimental Study on Rats. Int Surg 100: 891-896

de Souza VR, Pereira PA, da Silva TL, de Oliveira Lima LC, Pio R, Queiroz F (2014) Determination of the bioactive compounds, antioxidant activity and chemical composition of Brazilian blackberry, red raspberry, strawberry, blueberry and sweet cherry fruits. Food Chem 156: 362-368 doi:10.1016/j.foodchem.2014.01.125

Floegel A, Kim DO, Chung SJ, Koo SI, Chun OK (2011) Comparison of ABTS/DPPH assays to measure antioxidant capacity in popular antioxidant-rich US foods. J Food Compos Anal 24: 1043-1048

Food K, Association D (2005) Food standards codex Korean Foods Industry Association Seoul, Korea: 367-368

Francis FJ (1989) Food colorants: anthocyanins. Crit Rev Food Sci Nutr 28: 273-314

Hiramoto K, Johkoh H, Sako K, Kikugawa K (1993) DNA breaking activity of the carbon-centered radical generated from 2, 2-azobis (2amidinopropane) hydrochloride (AAPH). Free Radic Res Commun 19: 323-332

Horwitz W, Chichilo P, Reynolds H (1970) Official methods of analysis of the Association of Official Analytical Chemists Official methods of analysis of the Association of Official Analytical Chemists

Hyon JS, Kang SM, Han SW, Kang MC, Oh MC, Oh CK, Kim DW, Jeon YJ, Kim SH (2009) Flavonoid Component Changes and Antioxidant Activities of Fermented Citrus grandis Osbeck Peel. Journal of food science and nutrition 38: 1310-1316

Hyun TK, Song SC, Song CK, Kim JS (2015) Nutritional and nutraceutical characteristics of Sageretia theezans fruit. J Food Drug Analy 23: 742749

Jang HH, Nam SY, Kim MJ, Kim JB, Kim HR, Lee YM (2014) Antioxidant Activity and Protective Effects of Anthocyanins-Rich Fraction from Korean Purple Sweet Potato Variety, "Shinjami" against Oxidative Stress in HepG2 Cell. Korean J Food \& Nutr 27: 1090-1095

Jang HL, Yoon KY (2012) Biological Activities and Total Phenolic Content of Ethanol Extracts of White and Flesh-colored Solanum tuberosum L. Potatoes. J Korean Soc Food Sci Nutr 41: 1035-1040

Jubri Z, Rahim NBA, Aan GJ (2013) Manuka honey protects middle-aged rats from oxidative damage. Clinics (Sao Paulo) 68: 1446-1454

Kim J, Lee J, Park S (2011) Seed atlas of Korean plants. Academy Publishing, Seoul (in Korean)

Kumar S, Prahalathan P, Raja B (2011) Antihypertensive and antioxidant potential of vanillic acid, a phenolic compound in L-NAME-induced hypertensive rats: a dose-dependence study. Redox Rep 16: 208-215

Lee SO, Lee HJ, Yu MH, Im HG, Lee IS (2005) Total polyphenol contents and antioxidant activities of methanol extracts from vegetables produced 
in Ullung island. Korean J Food Sci and Technol 37: 233-240

Lee Y, Lee JH, Kim SD, Shang MS, Jo IS, Kim SJ, Hwang KT, Jo HB, Kim JH (2015) Chemical Composition, Functional Constituents, and Antioxidant Activities of Berry Fruits Produced in Korea. J Korean Soc Food Sci Nutr 44: 1295-1303

Lemañska K, Szymusiak H, Tyrakowska B, Zieliñski R, Soffers AE, Rietjens IM (2001) The influence of $\mathrm{pH}$ on antioxidant properties and the mechanism of antioxidant action of hydroxyflavones. Free Radic Biol Med 31: 869-881

Loo AY, Jain K, Darah I (2008) Antioxidant activity of compounds isolated from the pyroligneous acid, Rhizophora apiculata. Food Chem 107: $1151-1160$

Martineau LC, Couture A, Spoor D, Benhaddou-Andaloussi A, Harris C, Meddah B, Leduc C, Burt A, Vuong T, Mai Le P, Prentki M, Bennett SA, Arnason JT, Haddad PS (2006) Anti-diabetic properties of the Canadian lowbush blueberry Vaccinium angustifolium Ait. Phytomedicine 13: $612-623$

Naczk M, Shahidi F (2003) Phenolic compounds in plant foods: chemistry and health benefits. Nutraceuticals and Food 8: 200-218

Nanjo F, Goto K, Seto R, Suzuki M, Sakai M, Hara Y (1996) Scavenging effects of tea catechins and their derivatives on 1, 1-diphenyl-2picrylhydrazyl radical. Free Radic Biol Med 21: 895-902

Ozturk Sarikaya SB (2015) Acethylcholinesterase inhibitory potential and antioxidant properties of pyrogallol. J Enzyme Inhib Med Chem 30: 761-766

Pan MH, Chang YH, Badmaev V, Nagabhushanam K, Ho CT (2007) Pterostilbene induces apoptosis and cell cycle arrest in human gastric carcinoma cells. J Agric Food Chem 55: 7777-7785

Papandreou MA, Dimakopoulou A, Linardaki ZI, Cordopatis P, Klimis-Zacas D, Margarity M, Lamari FN (2009) Effect of a polyphenol-rich wild blueberry extract on cognitive performance of mice, brain antioxidant markers and acetylcholinesterase activity. Behav Brain Res 198: 352358

Park JC, Hur JM, Park JG, Hatano T, Yoshida T, Miyashiro H, Min BS, Hattori M (2002) Inhibitory effects of Korean medicinal plants and camelliatannin $\mathrm{H}$ from Camellia japonica on human immunodeficiency virus type 1 protease. Phytother Res 16: 422-426

Re R, Pellegrini N, Proteggente A, Pannala A, Yang M, Rice-Evans C (1999)
Antioxidant activity applying an improved ABTS radical cation decolorization assay. Free Radic Biol Med 26: 1231-1237

Sato M, Ramarathnam N, Suzuki Y, Ohkubo T, Takeuchi M, Ochi H (1996) Varietal differences in the phenolic content and superoxide radical scavenging potential of wines from different sources. J Agric Food Chem 44: 37-41

Seeram NP (2008) Berry fruits: compositional elements, biochemical activities, and the impact of their intake on human health, performance, and disease. J Agric Food Chem 56: 627-629

Seeram NP, Adams LS, Zhang Y, Lee R, Sand D, Scheuller HS, Heber D (2006) Blackberry, black raspberry, blueberry, cranberry, red raspberry, and strawberry extracts inhibit growth and stimulate apoptosis of human cancer cells in vitro. J Agric Food Chem 54: 9329-9339

Sellappan S, Akoh CC, Krewer G (2002) Phenolic compounds and antioxidant capacity of Georgia-grown blueberries and blackberries. J Agric Food Chem 50: 2432-2438

Seol GH, Kang P, Lee HS, Seol GH (2016) Antioxidant activity of linalool in patients with carpal tunnel syndrome. BMC Neurol. doi: 10.1186/ s12883-016-0541-3

Song SC, Song CK, Kim JS (2014) Vegetation and Habitat Environment of Sageretia thea in Jeju Island. Korean J Med Crop Sci 22: 301-305

Velika B, Kron I (2012) Antioxidant properties of benzoic acid derivatives against superoxide radical. Free Radicals and Antioxidants 2: 62-67

Wang M, Li J, Rangarajan M, Shao Y, LaVoie EJ, Huang TC, Ho CT (1998) Antioxidative phenolic compounds from sage (Salvia officinalis). J Agric Food Chem 46: 4869-4873

Wang SY, Jiao H (2000) Scavenging capacity of berry crops on superoxide radicals, hydrogen peroxide, hydroxyl radicals, and singlet oxygen. J Agric Food Chem 48: 5677-5684

Wang Z, Ma L, Zhang X, Xu L, Cao J, Jiang W (2015) The effect of exogenous salicylic acid on antioxidant activity, bioactive compounds and antioxidant system in apricot fruit. Scientia Hortic 181: 113-120

Yang DP, Ji HF, Tang GY, Ren W, Zhang HY (2007) How many drugs are catecholics Molecules 12: 878-884

Yu X, Zhao M, Liu F, Zeng S, Hu J (2013) Identification of 2,3-dihydro-3,5dihydroxy-6-methyl-4H-pyran-4-one as a strong antioxidant in glucosehistidine Maillard reaction products. Food Res Int 51: 397-403 